\title{
VALUES AND VALUE SHIFTS IN FOUR COUNTRIES OF SOUTH-EAST EUROPE: RETRADITIONALIZATION, EROSION OF TRUST AND THE DECLINE IN PUBLIC MORALITY
}

\author{
UDC 316.752(497.11/.15)
}

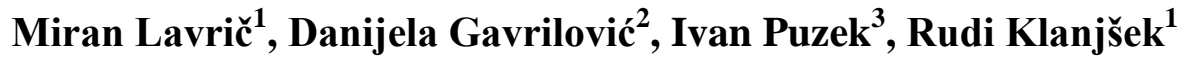 \\ ${ }^{1}$ University of Maribor, Faculty of Philosophy, Department of Sociology, Slovenia \\ ${ }^{2}$ University of Niš, Faculty of Philosophy, Department of Sociology, Serbia \\ ${ }^{3}$ University of Zadar, Department of Sociology, Croatia
}

\begin{abstract}
The paper considers the values and value orientations in four ex-Yugoslav republics (Bosnia and Herzegovina, Serbia, Croatia, and Slovenia). The starting point of the analysis are cross-national analyses of data from the World values survey (Inglehart et al.2014) and data presented by Shalom Schwartz (2013). Both approaches paint a similar picture of Slovenia being by far the closest to values typical for Western liberal democracies, while Bosnia and Herzegovina, and partially Serbia, are found on the opposite extreme. The longitudinal analyses suggest that in all the countries the studied values shifted in the direction of more traditional and survival values. More specifically, all four countries have witnessed an erosion of generalised social trust, a decline in public morality, and retraditionalization of gender roles. It is argued that these shifts should mainly be understood as a consequence of the enduring economic insecurities of the citizens, enhanced by the effects of the global economic crisis.
\end{abstract}

Key words: Balkans, Dialogue, Tolerance, Multiculturalism, Interculturalism, Measures of Public Cultural Policy.

\section{INTRODUCTION}

Bosnia and Herzegovina, Croatia, Serbia and Slovenia shared a similar socialist past and a common life in Yugoslavia for almost three quarters of the 20th century (1918-1992). Nevertheless, today there are quite substantial differences in terms of the social values and attitudes of the citizens of the four countries. These differences are the consequence of various levels of economic development, the path of transition which has been marked by

Received September 16, 2019 / Accepted October 23, 2019

Corresponding author: Miran Lavrič

University of Maribor, Faculty of Philosophy, Koroška cesta 160, 2000 Maribor, Slovenia

E-mail: miran.lavric@um.si 
specificities such as armed conflict in some of the countries, but also different cultural circles traditionally found in these countries (Cvitković 2012; Klanjšek, 2013).

A convenient starting point for presenting these differences, as well as similarities, is to show the position of each country on the famous Inglehart-Welzel cultural map (World Value Survey - worldsurvey.org). In this map, countries are presented in a twodimensional space, whereby the vertical axis represents a continuum from the traditional to secular-rational values, while the horizontal one represents a continuum from survival to self-expression values. ${ }^{1}$ As discernible from the latest (2015) version of the InglehartWelzel cultural map (Figure 1), the four countries in our focus basically belong to two different groups of countries in terms of the basic values of their inhabitants. While Slovenia and Croatia are positioned in the group denoted as "Catholic Europe", Serbia and Bosnia are found in the group of orthodox countries.

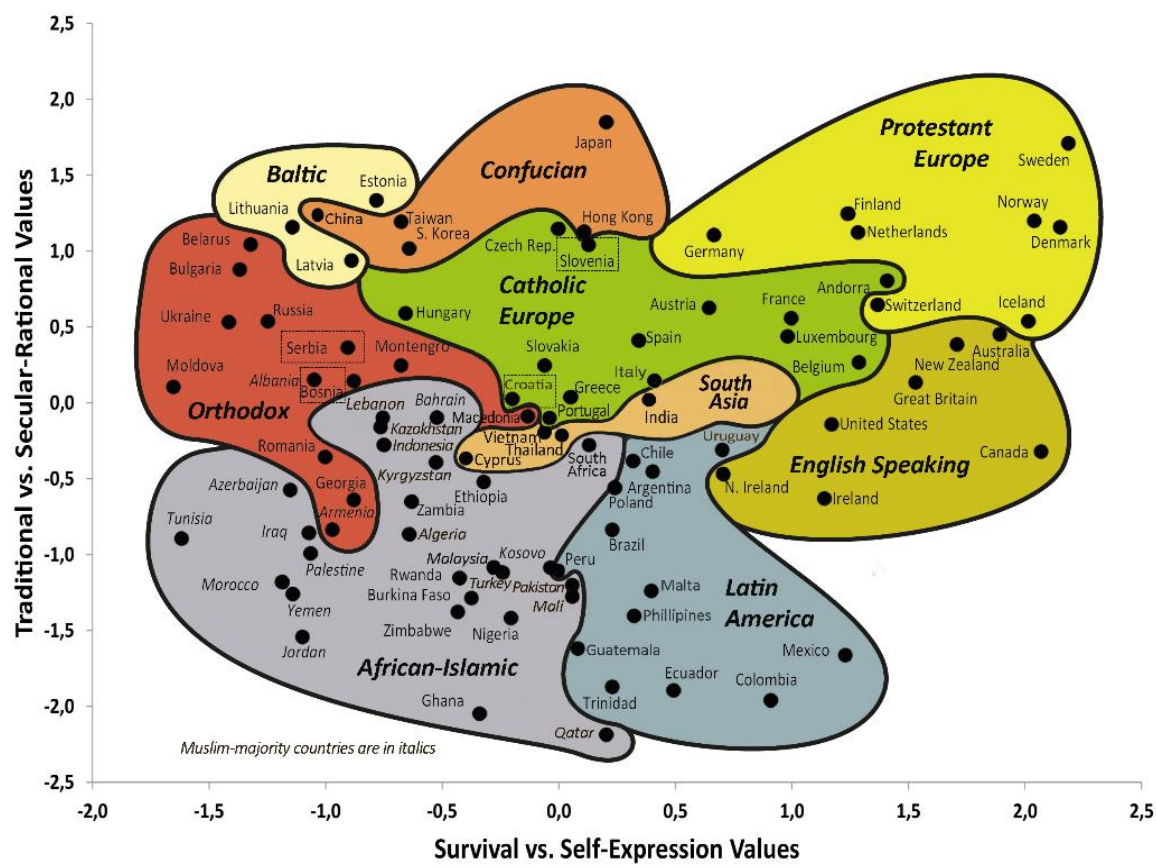

Fig 1 The Inglehart-Welzel Cultural Map

Source: World Values Survey (worldsurvey.org)

${ }^{1}$ The four sets of values are presented by Inglehart and Welzel (2005) in the following way:

"Traditional values emphasize the importance of religion, parent-child ties, deference to authority and traditional family values. People who embrace these values also reject divorce, abortion, euthanasia and suicide. These societies have high levels of national pride and a nationalistic outlook.

Secular-rational values have the preferences opposite to the traditional values. These societies place less emphasis on religion, traditional family values and authority. Divorce, abortion, euthanasia and suicide are seen as relatively acceptable.

Survival values place emphasis on economic and physical security. It is linked with a relatively ethnocentric outlook and low levels of trust and tolerance.

Self-expression values give high priority to environmental protection, growing tolerance of foreigners, gays and lesbians and gender equality, and rising demands for participation in decision-making in economic and political life." 
From a global perspective, we should further note that the two groups of countries (orthodox and European catholic) are next to each other, and that the four countries in our focus are relatively close to each other. In fact, one can easily discern the group of countries of central and South-East Europe with rather similar values (from left to right on the map this includes Serbia, Bosnia, Montenegro, Hungary, Croatia, Slovakia, the Czech Republic, and Slovenia). Thus, we can conclude that Bosnia, Croatia, Serbia, and Slovenia do share relatively similar basic social values when observed from the global perspective.

Upon closer inspection, however, differences between the four countries are notable. Along the horizontal axis, we find Slovenia and Croatia, positioned substantially higher on self-expression values, and Bosnia and Serbia much closer to survival ones. On the vertical axis, on the other hand, Slovenia displays by far the highest level of secular-rational values, while the other three countries are somewhere at the global average (zero value).

Slovenia also sticks out from the other three countries if we take into account another very influential approach to measuring values. It is the approach of Schwartz, who developed a theory of cultural values and created an empirically based model of seven cultural value orientations (Schwartz 2008). In a presentation given in Moscow in 2013, Schwartz presented a spatial map of 35 European countries according to the seven cultural value orientations (Schwartz 2013). In figure 2, we present a slightly simplified and modified map which will suffice for our purposes.

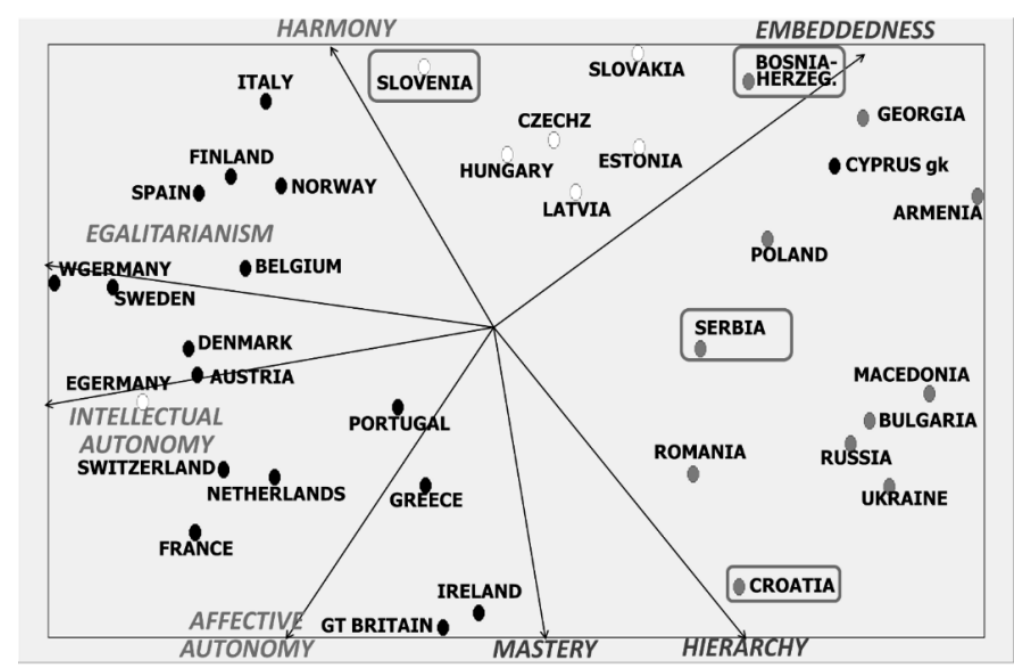

Fig. 235 European countries mapped on 7 cultural value dimensions by S. Schwartz (2013)

It is worth noting that value orientations on the left side of the map (autonomy, egalitarianism, and harmony) tend to be, at the level of individual countries, correlated with desirable societal characteristics, such as a functional democracy according to Freedom House, higher health expenditures as percent of GDP, lower levels of perceived corruption, and so on. The opposite is the case for value orientations on the right (mastery, hierarchy, and embeddedness).

It is not surprising, then, to see countries of Western Europe concentrated on the left side of the map, while the right side is mainly populated by countries of the post-socialist European East. 
The crucial finding regarding the four countries in our focus is the relatively remote position of Slovenia, which is, for instance, much closer to Norway and Finland than to the (geographically) neighbouring Croatia. While Slovenia is very high on the dimension on harmony and also egalitarianism, the other three countries are substantially closer to values emphasizing hierarchy and embeddedness. It should be noted that Schwartz's EmbeddednessAutonomy dimension is highly correlated to Inglehart's Survival-Self-Expression dimension (Dobewall and Strack 2014). Thus, the position of Bosnia and Serbia in this map overlaps with the relatively pronounced survival values of these countries in Inglehart-Welzel's cultural map. Schwartz $(2006,151)$ also found a strong negative correlation between his hierarchy orientation and Inglehart's secular-rational dimension. This sheds some light on the position of (very religious) Croatia being high on Schwartz's dimension of hierarchy and at the same time relatively low on Inglehart's secular-rational dimension.

As to the position of Slovenia, Schwartz found a strong positive correlation between harmony and secular-rational values: "More secular-rational societies are also societies that tend more to emphasize fitting into the natural and social world as it is, trying to understand and appreciate rather than to change or to exploit" (Schwartz 2006, 151). He finds such nations typically in secularized Western Europe, to which Slovenia, according to both Inglehart and Schwartz, is by far the closest among the four countries observed here.

Departing from the observed situation in relation to values of citizens of the four countries, we used survey data from 2017 in order to assess changes in some of the observed values and attitudes in the period between 2008 and 2017. More specifically, we focused on the issues which were included in the 2017 database and included social trust, public morality, and gender relations.

\section{METHOD}

The core data analyses in the current paper were based on data from surveys carried out between January and March 2015 on a probability sample of 3,906 respondents in total (national proportional samples of 1,000 respondents in Serbia and Croatia, 1,002 respondents in Bosnia-Herzegovina, and 904 respondents in Slovenia). The survey was implemented by a professional agency and based on face-to-face interviews part of the project "Life-Strategies and Survival Strategies of Households and Individuals in SouthEast European Societies in the Times of Crisis" (SCOPES). The data were organized in an SPSS file and analysed with basic tools of descriptive and inferential statistics.

For the purposes of longitudinal analyses, secondary analysis of the World values survey data (Inglehart et al. 2014) was also employed.

The applied instrument included following measures:

1. The classical question measuring generalised social trust with the following exact wording: "Would you say that most people can be trusted or that you need to be very careful in dealing with people?" (1 = "Most people can be trusted"; 2 = "Can't be too careful");

2. A set of questions measuring the level of trust in social groups and institutions. The initial question was: "In dealing with life's challenges and problems (to what extent) do you trust?" Respondents answered on a 1 (no trust) to 10 (full trust) scale for each of the 7 proposed groups/institutions (family members, friends, relatives, neighbours, colleagues, co-nationals, people of my religion, and state institutions); 
3. The permissibility of tax evasion and accepting bribes as measures of public good morality. Respondents were asked the question: "Please tell me whether, in your opinion, the following behaviors can always be justified, can never be justified, or something in between". For the purposes of this study, their answers on a 1 (never) to 10 (always) scale were used in relation to items "Evading taxes, if possible" and "Accepting/giving a bribe";

4. Traditional gender role attitudes, measured through agreement on a 1 (completely disagree) to 5 (completely agree) scale with four commonly used statements:

a. As a rule, men are more successful at work than women;

b. When unemployment is high, men getting hired should take precedence;

c. If a woman earns more than her spouse, family problems may arise; and

d. A young child is sure to suffer if the mother works.

Cronbach Alphas for the composite variable were between 0,57 (Slovenia) and 0,78 (Bosnia and Herzegovina), which is at least still acceptable (Kline 2000, 13) for every country.

\section{RESULTS}

We begin the presentation of our results with the issue of social trust. This topic has been one of central issues in social sciences at least since the early 1960's. According to Almond and Verba (1963), social trust is one of the key components of democratic political culture. The importance of social trust, however, goes well beyond democratic culture. As Mechanic and Meyer $(2000,657)$ put it, social trust is "fundamental to effective interpersonal relationships and community living". In short, social trust is crucial for effective social and economic functioning of any social group or society.

In the Figure 3 results based on the standard measure of generalized social trust (Moreno 2011, 2672) are presented.

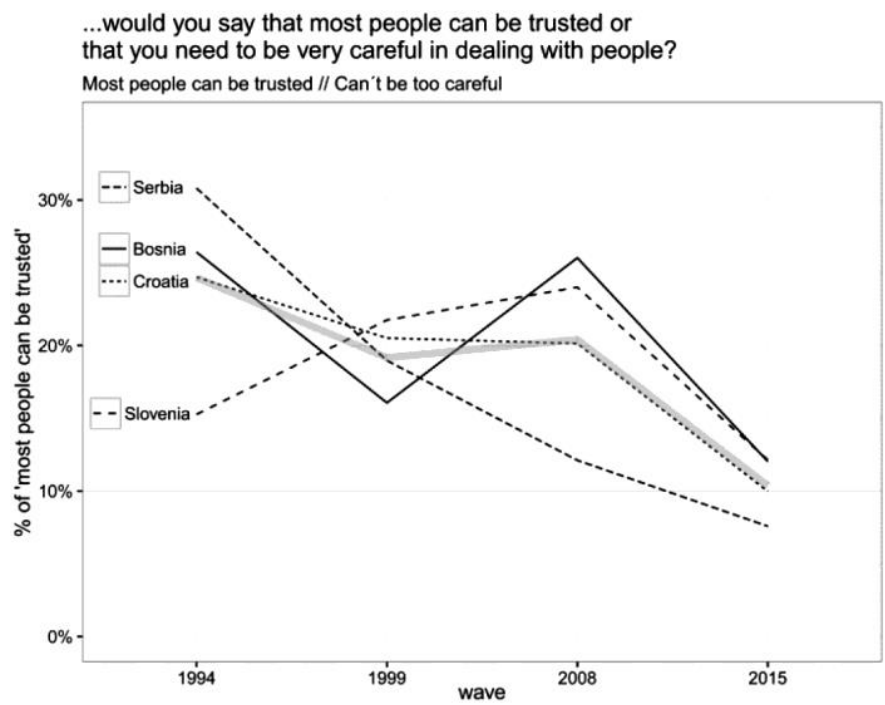

Fig. 3 The decline in generalized social trust Sources: World Value Survey (Inglehart et al. 2014), SCOPES project survey (2015) 
As discernible from the above figure, all four countries have witnessed a substantial erosion of social trust during the period after 2008. It should be added that the four countries observed have not only witnessed a sharp decline in generalized social trust during the past several years, but that their levels of trust are extremely low in cross-national comparison (between $8 \%$ in Serbia and $13 \%$ in B\&H). In 2008, for instance, only 14 out of 50 European countries in the EVS sample, had a share of trusting respondents below $20 \%$. And Denmark, a country with the highest level of generalized trust in the WVS sample, had for instance $76 \%$ respondents expressing trust in most people.

Thus, we are dealing with extremely low levels of generalized social trust, combined with a negative trend in all the four countries observed. Taking into account the body of literature pointing to a positive relationship between social trust on the one hand and socio-economic development and democracy on the other side, this breakdown of trust is anything but good news for the countries involved.

Another issue regarding social trust relates to the question which specific people or groups of people are most trusted by individuals in relative terms. More specifically, we dealt with the question of the 'radius of trust', that is, the question how general is trust in 'most people'. This radius of trust, according to Delhey, Newton and Welzel (2011), varies considerably across countries, with the tendency of wealthier countries having a wider radius. These authors further maintain that the radius of trust is an important factor of civic attitudes and behaviours, which, as Robert Putnam (2000) famously shows, are crucial for effective democracy.

The following graph presents average levels of trust in people belonging to different social groups in relation to the respondent. At the bottom of the graph, however, trust in state institutions is presented as an important point for comparisons and interpretations.

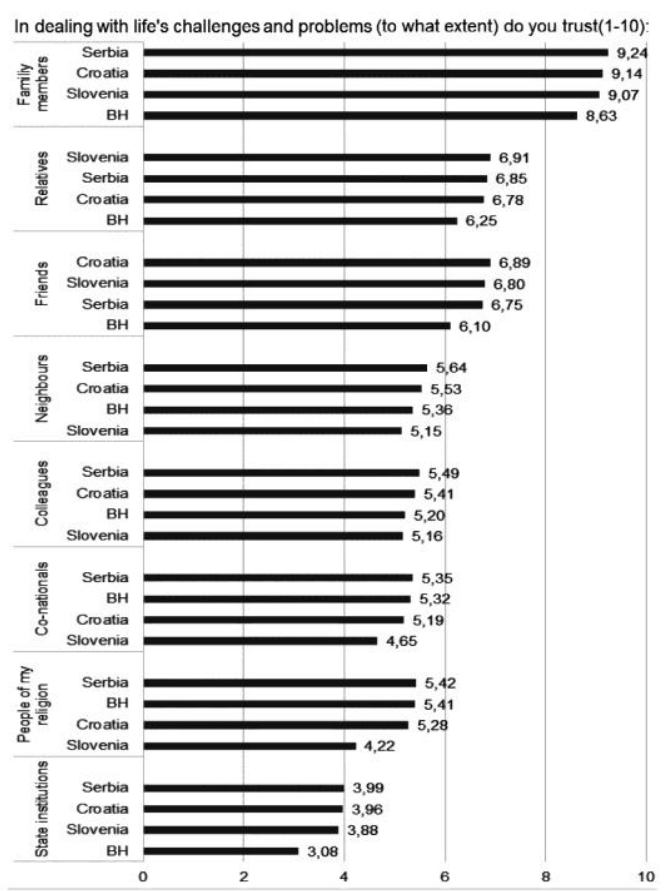

Fig. 4 Interpersonal trust levels vs. trust in institutions 
There are three groups achieving levels of trust beyond the mid-point of 5,5 (on the scale from 1 to 10); family, relatives and friends. Notably, there is a substantial gap between trust in family members and all other people. Although deeper analyses are undoubtedly needed, these findings generally point to the conclusion that family networks play a central role in social and economic life in the observed countries. To illustrate on the issue, we can use the case of Serbia, where $83 \%$ of the respondents express (almost) complete trust (options 9 or 10 ) in close family members, while less than $2 \%$ put such trust in state institutions.

With regards to trust in family members, as well as trust in relatives and friends, Slovenia and Croatia do not statistically significantly differ from Serbia. In fact, Bosnia and Herzegovina is the only one with statistically significant differences from (all three) other countries and it is in the direction of lower levels of trust regarding all three groups observed (close family, relatives and friends).

Notably, respondents from $\mathrm{B} \& \mathrm{H}$ also expressed relatively low levels of trust in neighbours, colleagues and in state institutions. This may come as a surprise in face of the fact that it is in exactly B\&H where we find the highest level of generalized social trust among the four countries observed. But as Delhey, Newton and Welzel (2011) show, generalized trust is not necessarily related to the radius of trust. Thus, we may argue that in $\mathrm{B} \& \mathrm{H}$ people appear to see themselves as (a little) more trusting than in the other three countries, but when thinking of concrete (groups of) people that surround them, their trust tends to subside. On the other hand, citizens of $\mathrm{B} \& \mathrm{H}$ express relatively high (highest next to Serbia) trust in co-nationals and people of their religion. Illustrative in this regard is the fact that $\mathrm{B} \& \mathrm{H}$ is the only country with higher levels of trust in people of one's religion than in one's neighbours. This might be explained by constant ethno-religious tensions, preceded by a war (1992-95) with a pronounced religious dimension (Flere 2014), making the ethno-religious frame of personal identity relatively important. Reinhard Henkel (2009) in this regard effectively speaks of 'confrontational identity'. Further analyses are needed to test and further explain these interpretations regarding issues of trust in $\mathrm{B} \& \mathrm{H}$. The opposite case from $\mathrm{B} \& \mathrm{H}$ appears to be found in Serbia, with the lowest level of generalized trust, but highest levels of trust in nearly all concrete options, with the minor exception of relatives and friends.

It should be stressed, however, that differences between the first three countries within each variable are for the most part statistically non-significant. Thus, differences between the countries should not deter us from seeing the general pattern characteristic of all the four countries observed. It is a pattern of a relatively narrow radius of trust, which is mainly limited to family, relatives and friends. State institutions, on the other hand enjoy extremely low levels of trust, with only $20 \%$ of the respondents at the level of entire sample expressing at least moderate (beyond 5 on a 1-10 scale) trust in them. If the very low levels of generalized social trust are added to this picture, it seems clear that all the countries observed have low levels of trust with a relatively narrow radius of trust, making their democratic and economic potential seriously hampered.

The second major topic of our concern was the concept of public good morality. We tested the longitudinal trends in this regard through the permissibility of tax evasion and accepting bribes. Both these actions can be understood as elements of public morality, that is, morality which is oriented towards the common, public good. Sieben and Halman $(2015,7)$ define it as: "...the (non)acceptance of behaviour that contravenes the law and harms society and the greater good of the collective, such as cheating on taxes if one has the chance, paying cash to avoid taxes, not paying one's fare in public transport, and claiming state benefits one is not entitled to". Clearly, tolerance towards tax evasion and accepting bribes falls into this category. 
Justification: accepting a bribe; cheating on taxes

...do you think that following actions can always be justified, never be justified, or something in between?

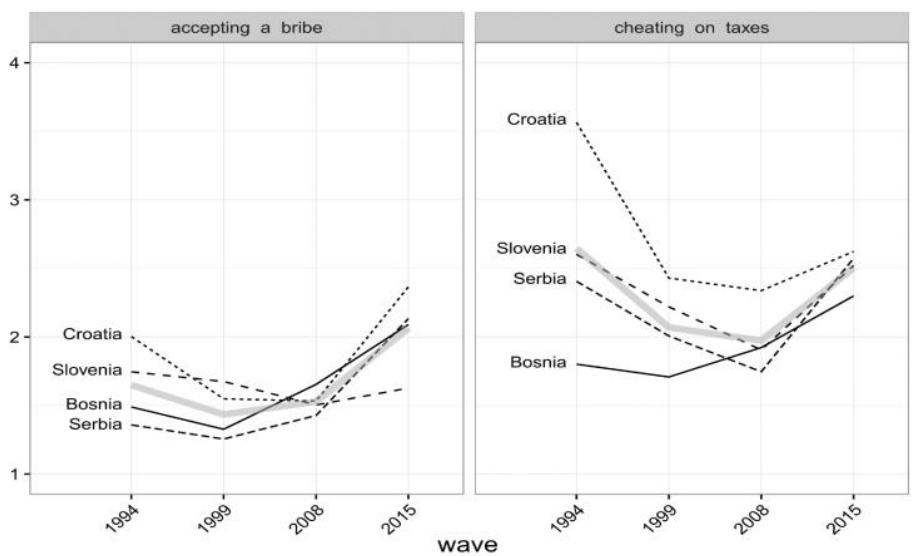

Fig. 5 Longitudinal trends regarding the public good morality

Sources: World Value Survey (Inglehart et al. 2014), SCOPES project survey (2015)

As we can see, in a period of global economic crisis (2008-2015) all four countries saw a quite substantial increase in tolerance towards tax evasion and accepting bribes, which means that they basically went through a process of decline in public morality. This kind of development is clearly not good news for these societies. As Sieben and Halman $(2015,8)$ put it: "An unbridled pursuit of personal over public gains will furthermore undermine collective solidarity and good citizenship, which are essential anchors of society".

Finally, in order to compare the situation in the four countries, we present the $95 \%$ confidence intervals for mean values of the composite measure of traditional gender role attitudes (TGRA).

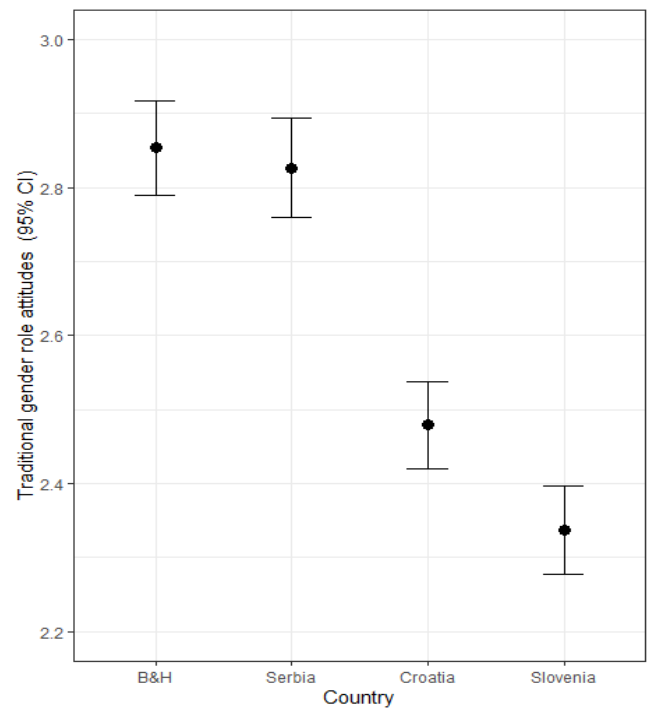

Fig. 6 Traditional gender role attitudes in four countries 
On the first note, it has to be stressed that mean values are well below the mid-point value of 3 on a five-point scale. At a closer look, even in two of the most traditionally oriented countries from our sample, less than $40 \%$ of the respondents had average values of their answers higher than the mid-point value ( 3 on a 1-5 scale). Thus, we may conclude that the statements included in the TGRA measure do not enjoy majority support in any of the countries observed.

Regarding the rankings of the four countries, the results are not surprising and resonate well with the reasoning put forward by Inglehart and Welzel (2005) that traditional gender attitudes tend to be less present in environments with higher levels of existential security. Our results are also very similar to the recent results attained by Kirbiš and Tavčar Krajnc (2013) who analysed differences between post-Yugoslav countries on the 2008 data of the World values survey.

Thus, in most 'existentially secure' Slovenia $\left(\mathrm{HDI}^{2}=0,874\right)$, gender role attitudes are most liberal, followed by Croatia (HDI=0,812), while in a less existentially secure Serbia $(\mathrm{HDI}=0,745)$ and Bosnia and Herzegovina (HDI=0,731), these attitudes are substantially more traditional.

One of the items from our TGRA measure also allowed us to make a comparison of percentages of respondents completely agreeing in years 2008 and 2015.

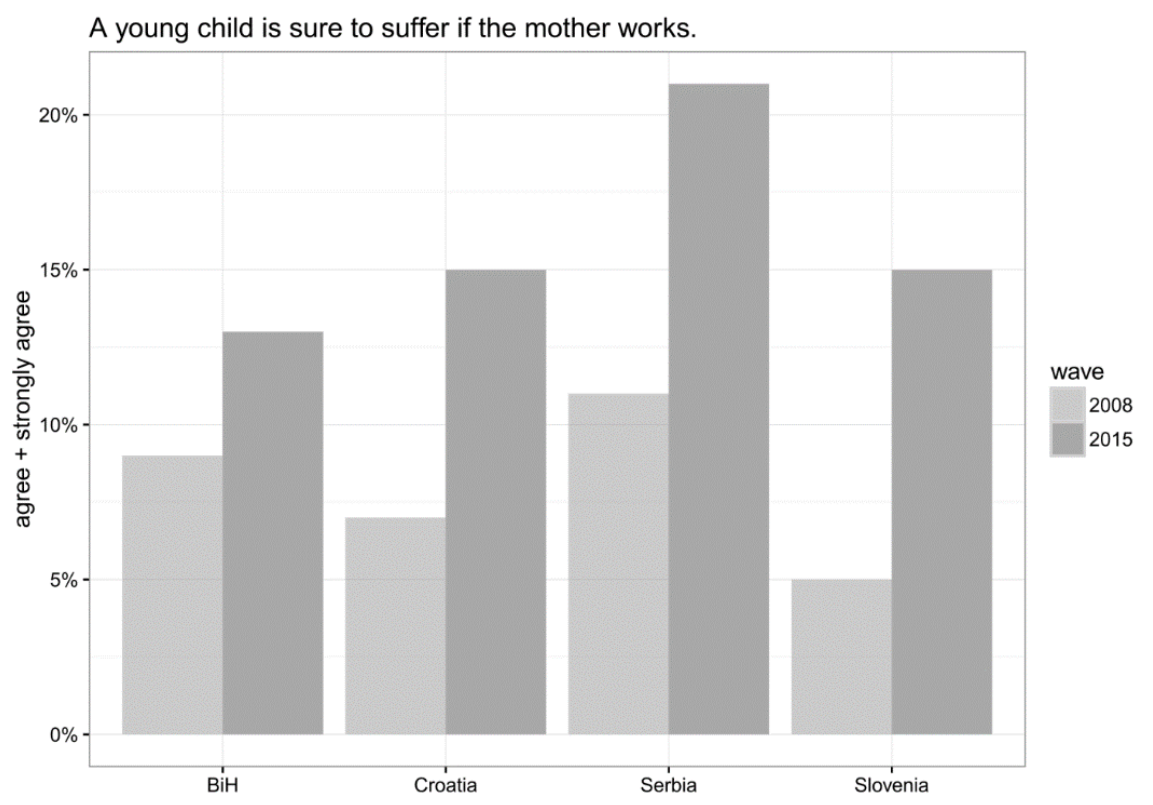

Fig. 7 Changes in agreement with a traditional gender role attitude, 2008-2015

Sources: World Value Survey (Inglehart et al. 2014), SCOPES project survey (2015)

\footnotetext{
${ }^{2}$ The human development index for the year 2013 is used as a proxy measure for existential security. This is a common solution (Norris and Inglehart 2015).
} 
As clearly observable from the above figure, agreement with the observed statement has increased substantially since 2008. We obtained similar results also on another measure of traditional gender role attitudes. ${ }^{3}$ On this basis we have good grounds to assume that, at least in some dimensions, re-traditionalization of social attitudes has taken place in the observed societies during the observed period.

\section{CONCLUSION}

The paper considers values and value orientations in Bosnia and Herzegovina, Serbia, Croatia, and Slovenia. These countries are similar in sharing a similar Yugoslav past (even though the differences between the republics were noticeable back then as well) and geographic proximity, but differ significantly in the sense of cultural heritage, ethnic composition, and transitional experience which was variedly marked by conflict, war, economic sanctions, and similar events. Today's economic development, despite different roads taken in the period of transition, reflects the differences from the Yugoslav period.

We used survey data from 2015 as a starting point for an analysis of the changes in the values among citizens of the four countries in the period between 2008 and 2015. The results point to a relatively sharp decline of general trust after 2008, even though this trust was relatively low even in 2008. Several studies (e.g. Putnam, 2000; Mechanic and Meyer, 2000) have shown that many modern societies suffered a substantial erosion of interpersonal and institutional trust regardless of economic trends. Regardless of the reasons for such a decline, there is a broad consensus among scholars that the erosion of trust tends to cause severe social consequences, leading to the "culture of anxiety" (Crawford 2004), or the "era of insecurity" (Bauman 1999). We believe that the decline of trust in the observed countries can best be explained by Inglehart's theory according to which interpersonal trust is associated with existential security (cf. Inglehart and Welzel 2005). The perceived change can be seen, at least in part, as a consequence of the economic crisis and its effects on the economic security of the citizens of the four countries.

Moreover, our results suggest that the so-called radius of trust is very narrow in all the four societies observed. Family members are the ones who are seen as by far the most trustworthy, followed by relatives and friends, while state institutions are entities with the lowest level of trust vested in them. Considering notions that a wide radius of trust is crucial for wider civic and social engagement, and consequently for an effective democracy, our findings in relation to social trust paint a relatively pessimistic picture in terms of future democratic development.

The second major finding of this study suggests a significant decrease in the public morality in all observed countries. Our data show that the citizens of all four countries are increasingly tolerant towards accepting bribes and evading taxes. Similarly as in the case of generalised social trust, these finding can be linked to relatively high levels of economic insecurity of the citizens of the four countries, which undoubtedly increased during the observed period (2008-2015), which was a period of a very slow and painful recovery from the effects of the global economic crisis.

Our analyses further suggest that economic insecurities are also a factor behind the observed retraditionalization of gender roles. Namely, in the most socio-economically

\footnotetext{
${ }^{3}$ It was the statement "When jobs are scarce men should have more right to a job than women". Unfortunately, response scales in 2008 and 2015 differed somewhat, so direct comparisons are not very reliable.
} 
developed Slovenia, gender role attitudes were found to be least traditionalist, while these attitudes were most traditionalist in the least socio-economically developed Bosnia and Herzegovina. While this finding is interesting and important, the much more important finding is, of course, the observed trend of retraditionalization of public attitudes in relation to gender role attitudes.

Quite obviously, this last finding fits well with the already established erosion of trust and public morality, and even more so with the finding of the narrow radius of trust. It seems that all four countries have been moving in the direction of survival and traditional values. Most likely largely due to high and increasing levels of economic uncertainties, the citizens of the observed countries were moving away from the values of selfexpression and also away from the rational-secular values.

This kind of reasoning is in full accordance with the so-called revised theory of modernization (Inglehart and Welzel 2005), according to which modernization is a process in which economic development, usually with a certain (generational) time lag, triggers cultural changes, which substantially increase the likelihood of emergence of a liberal democracy. This occurs because economic development increases peoples' material, cognitive, and social resources, and decreases their sense of existential insecurity. Thus, people tend to replace survival values with self-expression values, and traditional values with secular-rational ones. The theory does not maintain, however, that this process is irreversible. It also allows for the possibility that values can change in the direction of more survival and traditional orientations, most likely on account of people's increased sense of existential insecurity.

Acknowledgement: The paper is a part of the research done within the project Life-Strategies and Survival Strategies of Households and Individuals in South-East European Societies in the Times of Crisis. Financed by: the Swiss National Science Foundation (SNSF).

\section{REFERENCES}

Almond Gabriel A., and Sidney Verba. The Civic Culture: Political Attitudes in Five Western Democracies. Princeton, NJ: Princeton University Press, 1963.

Bauman, Zygmunt. In Search of Politics. Stanford, CA: Stanford University Press, 1999.

Crawford, Robert. "Risk Ritual and the Management of Control and Anxiety in Medical Culture". Health, An Interdisciplinary Journal for the Social Study of Health, Illness and Medicine 8, (2004): 505-528.

Cvitković, Ivan. Sociološki pogledi na naciju i religiju, II. Sarajevo: CEIR BiH, 2012.

Delhey, Jan, Kenneth Newton, and Christian Welzel. "How General Is Trust in 'Most People'? Solving the Radius of Trust Problem". American Sociological Review 76, 5 (2011): 786-807.

Dobewall, Henrik, and Micha Strack. "Relationship of Inglehart's and Schwartz's value dimensions revisited". International Journal of Psychology 49, 4 (2014): 240-48.

Flere, Sergej. "Was the Bosnian war (1992-95) a full fledged religious war?" In The Politicization of State, the Power of State, Nation and Faith", edited by Gorana Ognjenović and Jasna Jozelić, 33-53. London: Palgrave, 2014.

Henkel, Reinhard. "Religions and Religious Institutions in the Post-Yugoslav States between Secularization and Resurgence". Acta Universitatis Carolinae, Geographica (Karls-Universität Prag) 44 (2009): 49-61.

Inglehart, Ronald, \& Christian Welzel. Modernization, Cultural Change, and Democracy: The Human Development Sequence. New York: Cambridge University Press, 2005.

Inglehart, Ronald et al., eds. World Values Survey: All Rounds - Country-Pooled Datafile Version: http://www.worldvaluessurvey.org/WVSDocumentationWVL.jsp. Madrid: JD Systems Institute, 2014.

Kirbiš, Andrej, and Marina Tavčar Krajnc. "Gender Role Attitudes in Post-Yugoslav Countries: A Crossnational and Lngitudinal Analysis". In 20 Years After: Problems and Prospects of Countries of Former Yugoslavia, edited by Sergej Flere, 151-176. Maribor: CEPYUS, 2013. 
Klanjšek, Rudi. "Socio-economic Development after the Break-up of Yugoslavia". In 20 Years After: Problems and Prospects of Countries of Former Yugoslavia, edited by Sergej Flere, 95-130. Maribor: CEPYUS, 2013.

Kline, Paul. 2000. The handbook of psychological testing (2nd ed.). London: Routledge, 2000.

Mechanic, David, and Sharon Meyer. "Concepts of Trust among Patients with Serious Illness". Social Science \& Medicine 51, 5 (2000): 657-68.

Moreno, Alejandro. "Trust, Social”. In International Encyclopedia of Political Science, edited by Bertrand Badie, Dirk Berg-Schlosser \& Leonardo Morlino, 2672-2674. London: Sage, 2011.

Norris, Pippa, Ronald Inglehart. "Are High Levels of Existential Security Conducive to Secularization? A Response to Our Critics.” In The Changing World Religion Map: Sacred Places, Identities, Practices and Politics, edited by Stan Brunn, 3389-3408. Springer, 2015.

Putnam, Robert D. Bowling Alone: The Collapse and Revival of American Community. New York, NY: Simon \& Schuster, 2000 .

Schwartz, Shalom. "A Theory of Cultural Value Orientations: Explication and Applications". Comparative Sociology 5, 2/3 (2006): 137-182.

Schwartz, Shalom. Cultural Value Orientations: Nature \& Implications of National Differences. Jerusalem: The Hebrew University of Jerusalem, 2008.

Schwartz, Shalom. "Cultural Values as Constraints and Facilitators of Socio-economic Change". Powerpoint presentation for the lecture at the Higher School of Economics, Moscow. Accessed July 5, 2018.https://www.hse. $\mathrm{ru} / \mathrm{en} / \mathrm{ma} / \mathrm{socpsy} / \mathrm{news} / 100399092 . \mathrm{html}$

Sieben, I. \& L. Halman. Morality and Public Good in Post-Socialist European States? Studies of Transition States and Societies 7, 1 (2015): 7-26.

World Values Survey. "Findings and Insights". Accessed on July 10, 2018.http://www.worldvaluessurvey. org/WVSContents.jsp?CMSID=Findings

\section{VREDNOSTI I PROMENE VREDNOSTI U ČETIRI ZEMLJE JUGOISTOČNE EVROPE: PONOVNA TRADICIONALIZACIJA, POTKOPAVANJE POVERENJA I PAD JAVNOG MORALA}

Ovaj rad razmatra vrednosti $i$ orijentacije vrednosti u četiri bivše jugoslovenske republike (Bosna i Hercegovina, Srbija, Hrvatska i Slovenija). Polazna tačka analize su analiza podataka iz istraživanja vrednosti u svetu (Inglehart et al. 2014) i podaci koje je predstavio Schwartz (2013). Oba pristupa daju sličnu sliku Slovenije koja je daleko najbliža vrednostima tipičnim za zapadne liberalne demokratije, dok se Bosna i Hercegovina, a delimično Srbija, nalaze na suprotnom kraju spektruma. Longitudinalne analize pokazuju da su se u svim analiziranim državama vrednosti pomerile u pravcu tradicionalnijih vrednosti $i$ vrednosti preživljavanja. Tačnije, sve četiri zemlje doživele su potkopavanje opšteg poverenja, pad javnog morala i ponovnu tradicionalizaciju rodnih uloga. Tvrdi se da bi te promene uglavnom trebalo razumeti kao posledicu dugotrajne ekonomske nesigurnosti građana, uvećane posledicama globalne ekonomske krize.

Ključne reči: Jugoistočna Evropa, vrednosti, ponovna tradicionalizacija, poverenje, javni moral. 